\title{
Polyethyleneimine Modified Carbon Cloth Anode for Self-Pumping Enzymatic Glucose Biofuel Cell
}

\author{
Li Z. Huang, Ngoc Bich Duong, Jhang H. Wang, and Hsiharng Yang (iD \\ Graduate Institute of Precision Engineering, National Chung Hsing University, Taichung 402, Taiwan \\ Correspondence should be addressed to Hsiharng Yang; hsiharng@nchu.edu.tw
}

Received 2 January 2018; Revised 27 March 2018; Accepted 8 April 2018; Published 14 May 2018

Academic Editor: Abhijeet P. Borole

Copyright (c) 2018 Li Z. Huang et al. This is an open access article distributed under the Creative Commons Attribution License, which permits unrestricted use, distribution, and reproduction in any medium, provided the original work is properly cited.

\begin{abstract}
This paper proposes a simplified process that immobilizes enzymes onto carbon cloth electrodes to increase biofuel cell functionality. Polyethyleneimine (PEI) is used to modify carbon cloth electrodes to reduce the processing time and increase selfpumping enzymatic glucose biofuel cell (self-pumping EGBC) electricity. PEI is usually used in biochemical engineering gene transfection as GOx support to enhance enzyme immobilization. PEI is a good candidate for increasing enzymatic biofuel cell (EBC) redox current. PEI and GOx have been successfully immobilized onto carbon cloth electrodes through FT-IR analysis. A UV/Vis spectrophotometer was used to investigate the best PEI support concentration. PEI was proven to improve redox current by cyclic voltammetry analysis. The results show that the GOx/PEI electrode has excellent hydrophilicity on the GOx/PEI electrode surface using contact angle measurement. The optical and electrochemical analysis result shows that GOx/PEI was successfully immobilized onto carbon cloth electrodes. Experimental analysis showed that self-pumping EGBC achieved a power output of $0.609 \mathrm{~mW} / \mathrm{cm}^{2}\left(126.9 \mathrm{~mW} / \mathrm{cm}^{3}\right)$. PEI contributes to the shortening of the process from a few hours to 5-10 minutes and enhances GOx fuel cell performance.
\end{abstract}

\section{Introduction}

Science and technology continuously change and rapidly improve. Raw materials are the fundamental source of human civilization; however, now people face energy depletion and environmental pollution problems. To protect the natural environment for sustainable continuity, a variety of energy regeneration, durability, and green energy technologies have been developed. Fuel cells use a chemical system to convert chemical energy into electrical energy. The proton exchange membrane and methanol fuel cells are new generations of high conversion efficiency green energy power systems. However, fuel cell catalysts generally require platinum and other precious metals to function, greatly increasing the manufacturing cost. Another type of fuel cell is a biofuel cell derived from biofuel chemical reactivity. Biofuel cells have traditionally been classified into microbial fuel cells and enzymatic biofuel cells based on the type of catalyst. The microbial fuel cell uses complete organisms for the catalytic reaction and the cell system structure is relatively large. Enzymatic biofuel cells use glucose as fuel, generating electrical power by oxidation-reduction. Although microbial biofuel cells have the advantage of long lifetime $[1,2]$, the power densities of these devices are typically lower owing to the mass transfer resistance across cellular membranes. Moreover, enzymatic biofuel cells have the problem of reduced stability due to the limited lifetime of extracellular enzymes. However, they can provide higher power densities (although still lower than conventional fuel cells) because of the lack of mass transfer barriers. The enzymatic fuel cell is used in medical implants, remote sensors, and low-power electrical devices [3]. In a bid to improve power density and lifetime, establishing enzyme immobilization is important.

In the past few years enzyme immobilization strategies have included adsorption, covalent binding, and crosslinking [4-6]. In 1999, Anderson and Kaul investigated the PEI effect on protein stability. Lactic dehydrogenase experiments were conducted which used different additives and concentrations for comparison [7]. The shelf stability at $36^{\circ} \mathrm{C}$ was distinctly improved in the presence of $0.01-1 \%$ 
$(\mathrm{w} / \mathrm{v})$ polymer. This result proved that PEI could effectively improve the protein shelf life [7]. PEI is a conductive polymer and serves as a pathway for electron transfer from the flavin adenine dinucleotide (FAD) of GOx to the carbon material substrate [8]. In 2014, Xu et al. performed research fabricating a Pd-PEI/GO/GC electrode using a layer-by-layer method. The results demonstrated that the Pd-PEI/GO/GC electrode exhibited high electrocatalytic activity toward $\mathrm{H}_{2} \mathrm{O}_{2}$ reduction [9]. PEI is a positively charged polyamine that contains abundant amine groups and has been used to modify metallic nanoparticles due to the interaction between the amine groups and metal atoms [9]. Deng and coworkers [10] presented a sensitive and stable biosensor that employed GOx immobilized on the negatively charged CNT surface by alternatively assembling a cationic (PEI) layer and a GOx layer. Their results indicated that the GOx/PEI film played an important role in retaining the bioactivity of the immobilized GOx. Also, the PEI layer which was used as an out-layer adsorbed on the top of the GOx/PEI film improved the stability of the enzyme electrode [10]. The EBC performance is strongly dependent on not only the enzymes used and how they are immobilized on the electrode, but also several other conditions such as $\mathrm{pH}$ and temperature. Vogt et al. [11] determined that the development of the EBC anodes working at the $\mathrm{pH} 7.4$ and $\mathrm{pH} 7$ was of main interest. In 2016, Yang et al. [12] improved the GOx retained activity in the optimum $\mathrm{pH}$ 7.0-7.2 range. Moreover, most EBC performance tests with the glucose solution $\mathrm{pH} 7$ as the anode inlet fuel supplied have been studied $[2,10,13-16]$.

This study utilizes PEI to enhance GOx enzyme immobilization. A passive system is used in these experiments which drives fuel by itself through the capillary effect. Compared to active systems the fuel cell scale is much smaller and works without needing an extra pump. PEI is applied to modify the carbon cloth electrode to reduce the processing time and increase self-pumping EGBC electricity. Cyclic voltammetry curves are measured to determine the electron transfer rate constant, while FTIR measurement is carried out to inspect whether PEI and GOx are properly incorporated onto the carbon cloth. The electrode surface is observed using SEM. Self-pumping EGBC polarization curves are measured to obtain the maximum power density.

\section{Experiments}

2.1. Materials. Glucose oxidase from Aspergillus niger (type Lyophilized powder, 128200 units/g solid) was obtained from Novo Nordisk Bioindustrial Inc. (Copenhagen, Denmark). Carbon cloth was obtained from CeTech Co. (domestic company). Polyethyleneimine was purchased from SigmaAldrich. N-(3-Dimethylaminopropyl)- $\mathrm{N}^{\prime}$-ethylcarbodiimide hydrochloride (EDC, 98\%) and N-Hydroxysuccinimide (NHS, 98\%) were obtained from Sigma-Aldrich. Nafion ${ }^{\circledR} 117$ membranes (DuPont) were pretreated before being applied to the electrode.

2.2. Preparation of Enzyme Electrode. PEI was applied to carbon cloth as an enzyme carrier to modify the electrode. The enzyme was then immobilized onto the carrier. This
TABLE 1: The anode and cathode solution composition.

\begin{tabular}{lc}
\hline Electrolyte & Components \\
\hline & $0.1 \mathrm{M} \mathrm{pH} 7 \mathrm{PBS}$ \\
Anode solution & $0.1 \mathrm{M} \mathrm{C}_{6} \mathrm{H}_{12} \mathrm{O}_{6}$ \\
& $0.1 \mathrm{M} \mathrm{NaCl}$ \\
\hline \multirow{2}{*}{ Cathode solution } & $0.1 \mathrm{M} \mathrm{pH} 7 \mathrm{PBS}$ \\
& $0.1 \mathrm{M} \mathrm{K}_{3} \mathrm{Fe}(\mathrm{CN})_{6}$ \\
\hline
\end{tabular}

study used $3 \times 3 \mathrm{~cm}^{2}$ carbon cloth as the immobilization substrate. The immobilization process is divided into two parts. First is the immobilization onto PEI. PEI is adsorbed onto the carbon cloth by adding $3 \times 3 \mathrm{~cm}^{2}$ of carbon cloth into a PEI solution ( $4 \mathrm{wt} \%)$ and mixing thoroughly. The carbon cloth was dried for 5-10 minutes. A phosphate buffer solution (PBS) (pH 6, $50 \mathrm{mM}$ ) is prepared next. Then $0.039 \mathrm{~g}$ of $\mathrm{GOx}$ is added to the PBS ( $\mathrm{pH} 6,50 \mathrm{mM}$ ) and stirred until completely dissolved. Four $\mathrm{mg} / \mathrm{ml}$ of EDC (N-(3-dimethylaminopropyl)$\mathrm{N}^{\prime}$-ethylcarbodiimide) is then added and shaken for 1 hour, activating the enzyme. This is followed by adding $2.4 \mathrm{mg} / \mathrm{ml}$ of NHS (N-hydroxysuccinimide). The mixture is shaken again for one hour. This step transforms the enzyme into a stable state to avoid reduction. Finally, PEI/carbon cloth is placed into the active GOx solution and shaken for 50 minutes, producing a completed GOx/PEI/carbon cloth enzyme electrode.

2.3. Self-Pumping Enzymatic Glucose Biofuel Cells. The whole EBC stack and its components are shown in Figure 1 which consists of top and bottom end plates, PDMS gasket, cathode and anode flow field plate, current collectors, rubber gasket, the modified cathode, and anode electrodes. The Nafion 117 membrane is located between the two electrodes composed as a sandwich structure. The elements are stacked in layers and then stabilized using screw locks. Fuel is driven into the fuel cell using capillary force without any extra pump. The cathode electrode is carbon paper-coated $\mathrm{Pt}$ while the anode electrode is covered by GOx/PEI/carbon cloth. The fuel used as the anolyte is a mixed $0.1 \mathrm{M}$ glucose, $0.1 \mathrm{M} \mathrm{NaCl}$, and $0.1 \mathrm{M}$ PBS pH 7 solution.

2.4. Electrochemical Analysis. The working electrode is a test piece that was measured. The reference electrode was used to measure the test piece potential in the current environment. Pt was used as a counter electrode and $\mathrm{Ag} / \mathrm{AgCl}$ was used as the reference electrode. The auxiliary electrode supports current and remains electrically neutral by forming a loop with the test piece. Throughout the experiment, the magnitude of the output current and voltage were controlled using a potentiostat. The self-pumping EGBC anode and cathode compositions are shown in Table 1, in which the PBS $\mathrm{pH} 7$ solution is used.

\section{Results and Discussion}

3.1. FTIR Analysis. The chemical structures of PEI, PEI/ carbon cloth, GOx, and GOx/PEI/carbon cloth were characterized using FTIR spectroscopy as shown in Figures 2 and 3, respectively. 


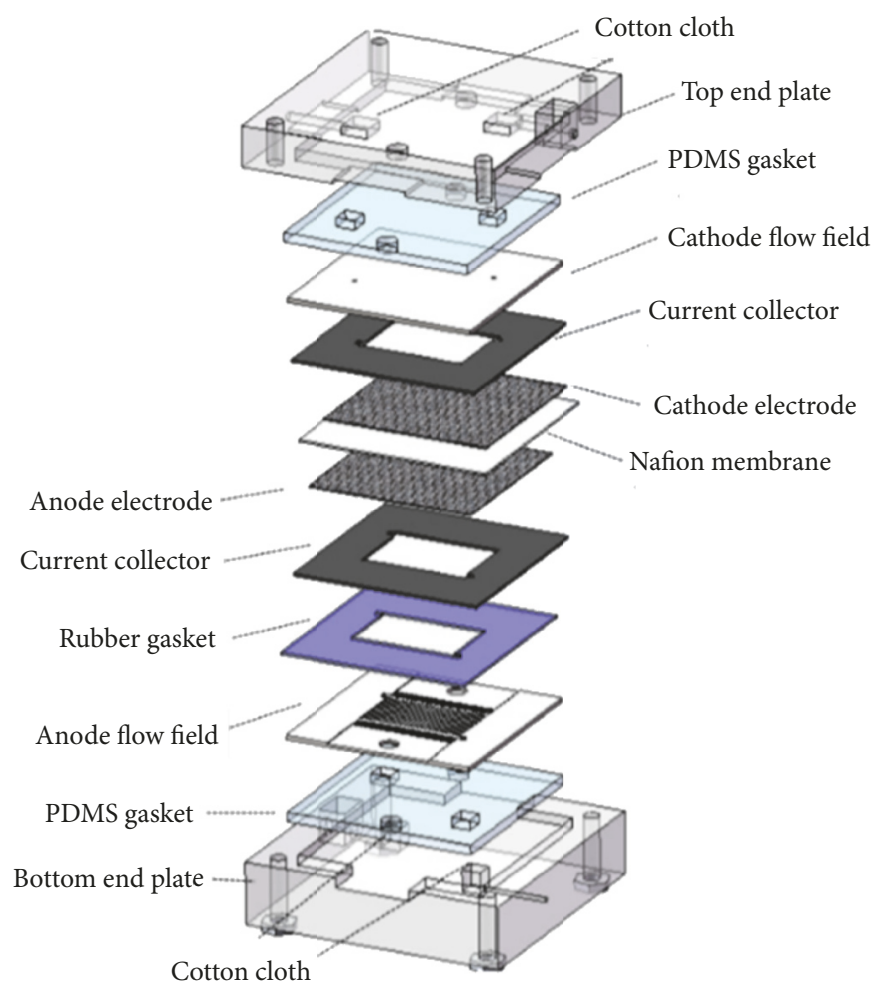

Figure 1: Schematic diagram of the self-pumping enzymatic glucose biofuel cell.

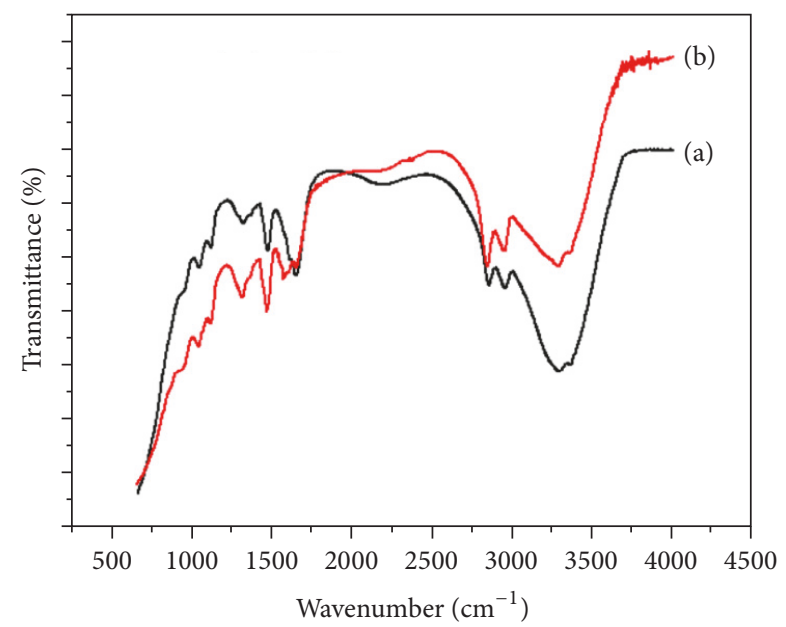

(a) PEI

(b) PEI/carbon cloth

FIGURE 2: The FTIR analysis of monomer and carbon cloth immobilized. (a) PEI. (b) PEI/carbon cloth.

The molecular structure of PEI is N-H $\left(3272 \mathrm{~cm}^{-1}\right), \mathrm{C}-\mathrm{H}$ $\left(2940 \mathrm{~cm}^{-1}-2830 \mathrm{~cm}^{-1}\right), \mathrm{N}-\mathrm{H}\left(1576 \mathrm{~cm}^{-1}\right), \mathrm{C}-\mathrm{H}\left(1465 \mathrm{~cm}^{-1}\right)$, C-N (1350-1000 $\left.\mathrm{cm}^{-1}\right)$, and so on. After comparing the FTIR analysis results against the PEI functional group literature, we found that the PEI spectral waveform structure was similar to that in the literature. The analysis results showed that PEI was immobilized onto the carbon cloth electrode, as shown in Figure 2. The main GOx absorption peak was in the

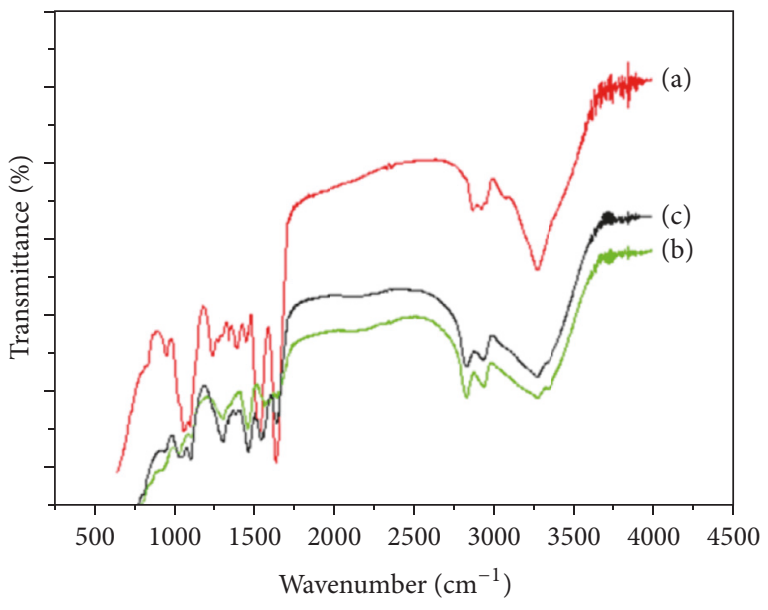
(a) GOx
(b) $\mathrm{PEI} /$ carbon cloth
(c) GOx/PEI/carbon cloth

FIGURE 3: The FTIR analysis of carbon cloth electrode immobilized. (a) GOx. (b) PEI/carbon cloth. (c) GOx/PEI/carbon cloth.

$1400-1800 \mathrm{~cm}^{-1}$ range, caused by the $\mathrm{NH}_{2}\left(1644 \mathrm{~cm}^{-1}\right)$ and $\mathrm{N}-\mathrm{H}\left(1541 \mathrm{~cm}^{-1}\right)$ bending vibration. As shown in Figure 3, the curve (a) was the GOx spectrum, (b) the PEI carbon electrode spectra immobilized on carbon cloth, and (c) the enzyme immobilized on the PEI carbon cloth electrode. The GOx characteristic peaks were on the enzyme electrode and we can distinguish that the enzyme was successfully immobilized onto the carbon cloth. 


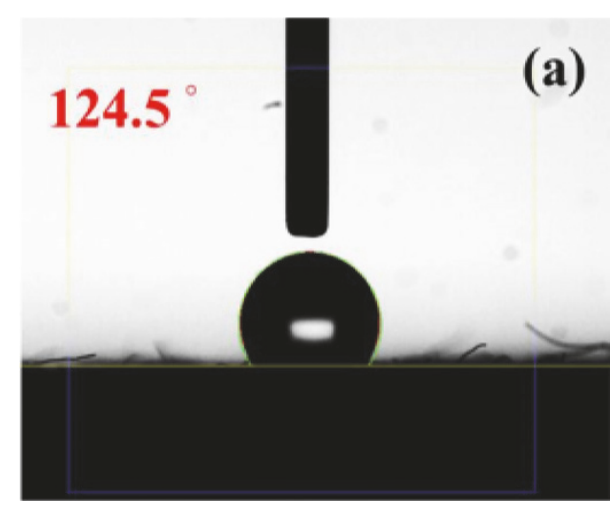

(a)

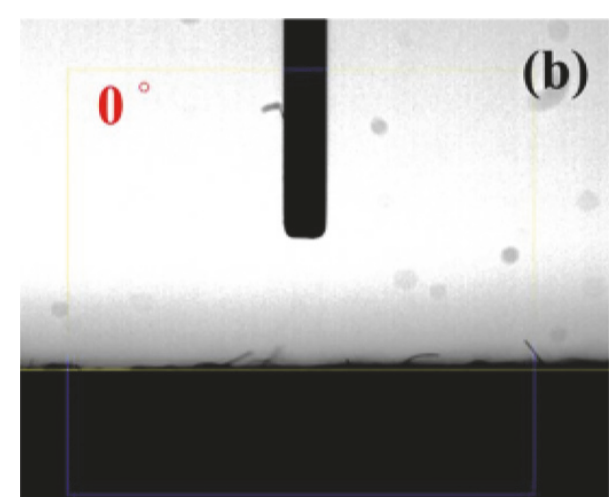

(b)

FIGURE 4: The contact angle measurement of carbon cloth electrode surface. (a) Before modification. (b) After modification.

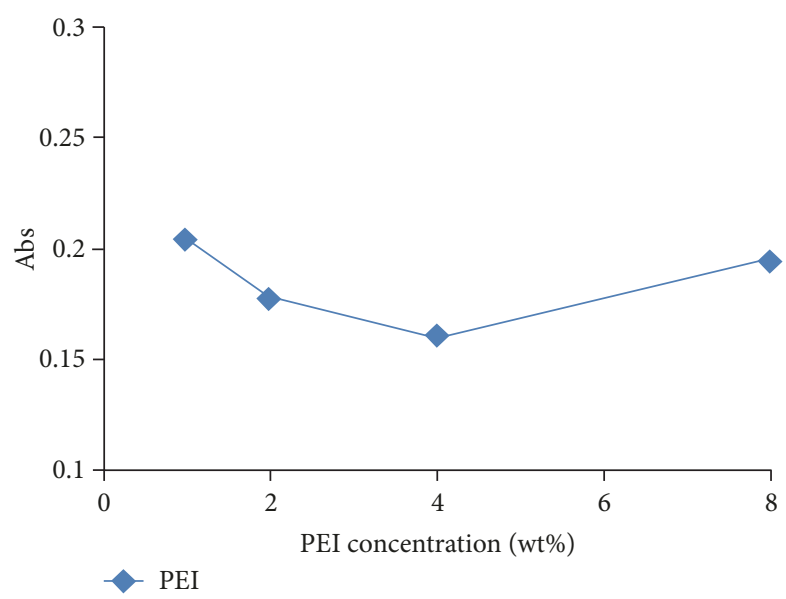

FIGURE 5: Enzyme adsorption analysis at different PEI concentrations.

3.2. Electrode Contact Angle Measurement. The capillary force pumping fluid for self-pumping EGBC requires higher hydrophilic properties at the anode and cathode electrodes. Using the Optical Contact Angle Meter Model 100SB, the original carbon cloth used as the anode and cathode sides of the self-pumping EBC are hydrophobic with a surface contact angle of $138.80^{\circ}$ (Figure 4(a)). To modify the carbon cloth electrode surface into hydrophilic, the carbon cloth was immersed into a mixture of acids $\left(\mathrm{H}_{2} \mathrm{SO}_{4}: \mathrm{HNO}_{3}=3: 1\right)$ and then sonicated for $5 \mathrm{~min}$ to produce hydrophilic carboxyl functional groups $(\mathrm{COOH})$ [18]. The surface is therefore hydrophilic with no contact angle, so the contact angle is defined as $0^{\circ}$, as shown in Figure 4(b).

3.3. UV/Vis Spectrophotometer. PEI/carbon cloth with different PEI concentrations was added to the enzyme solution to remove the enzyme. We then measured the remaining GOx protein concentration in each tube. If the tube absorption value was lower, it means the $\mathrm{PEI} /$ carbon cloth adsorbed more enzymes. After immobilization at $4 \mathrm{wt} \% \mathrm{PEI} /$ carbon cloth, the lowest absorbance was 0.16 at the wavelength of $595 \mathrm{~nm}$. This means the PEI/carbon cloth electrode adsorbed more enzyme in $4 \mathrm{wt} \%$ PEI, as shown in Figure 5. Excessive

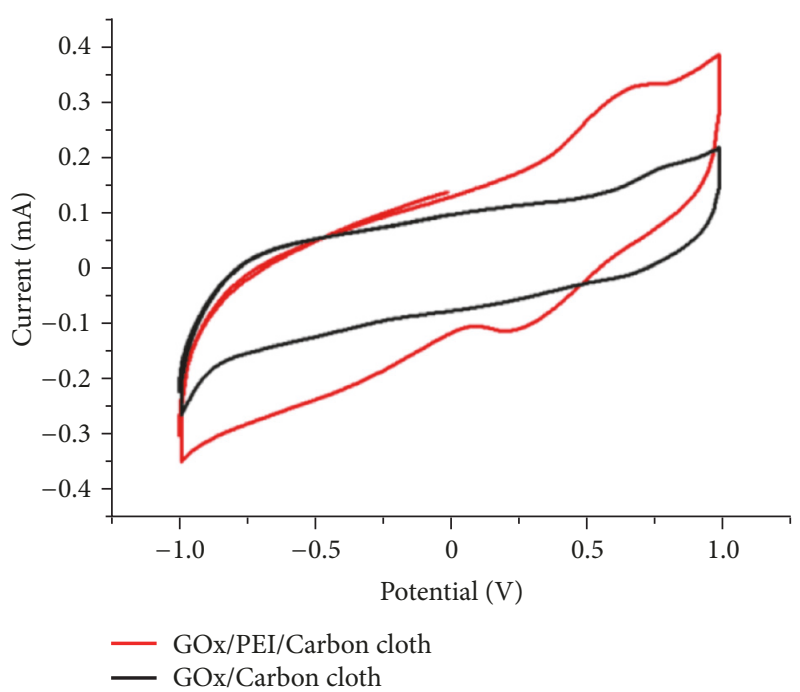

Figure 6: Cyclic voltammetry of GOx/PEI/carbon cloth and GOx/carbon cloth.

PEI concentration may block carbon cloth pores, causing lower specific surface area, making the mechanical properties not enough to affect the enzyme adsorption rate.

3.4. Electrochemical Analysis. The CVs of the catalysts were performed using a 3-electrode system (Zennium E Electrochemical Workstation) with an $\mathrm{Ag} / \mathrm{AgCl}$ reference electrode, a Pt wire counter electrode, and the working electrode of the $\mathrm{GOx} /$ carbon cloth and GOx/PEI/carbon cloth submerged in the solution of $0.1 \mathrm{M}$ glucose and $0.1 \mathrm{M} \mathrm{NaCl}$ at the potential range of $+1.0 \mathrm{~V} \sim-1.0 \mathrm{~V}$ and the scan rate of $0.1 \mathrm{~V} \cdot \mathrm{s}^{-1}$. Enzyme electrodes with PEI were compared with enzyme electrodes without PEI. The analysis results showed that the former had a higher cyclic voltammetry value and the overall reaction area was larger. The redox current peak was at maximum while the later without PEI obtained a slightly small peak. That showed us that PEI substrate enzyme electrode addition had a higher biocompatibility and maintained enzyme activity, so it produced a better redox reaction, as shown in Figure 6. 


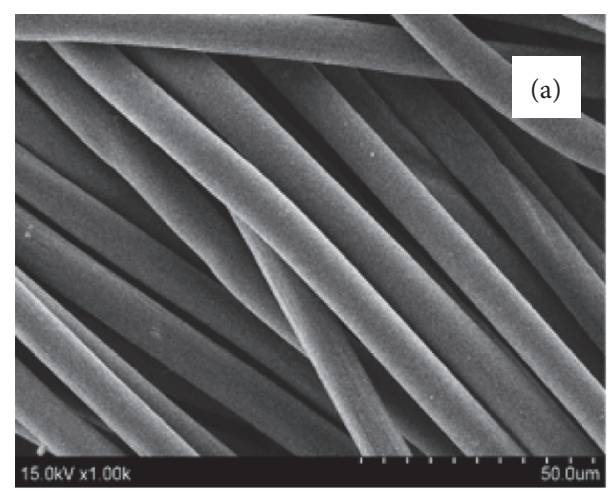

(a)

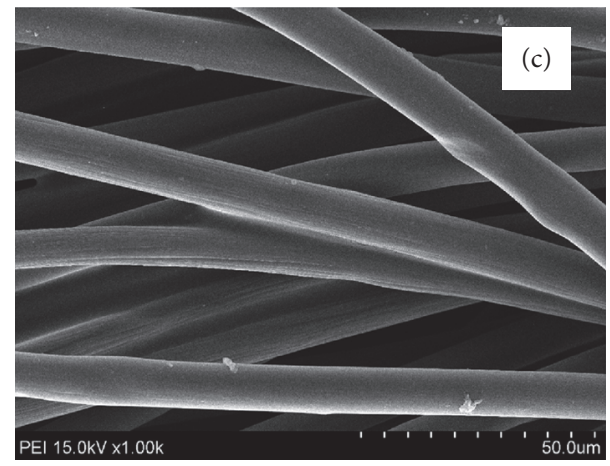

(c)

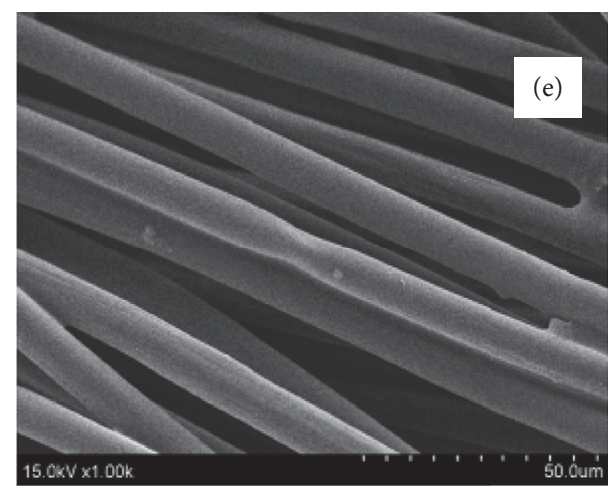

(e)

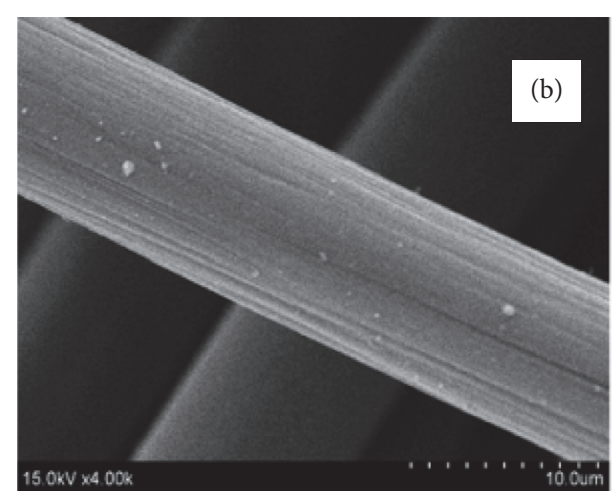

(b)

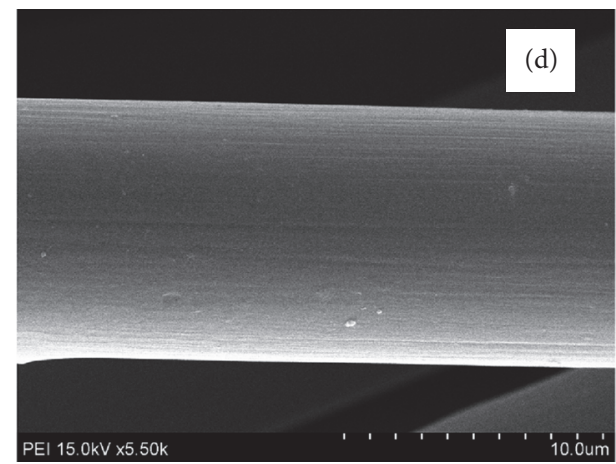

(d)

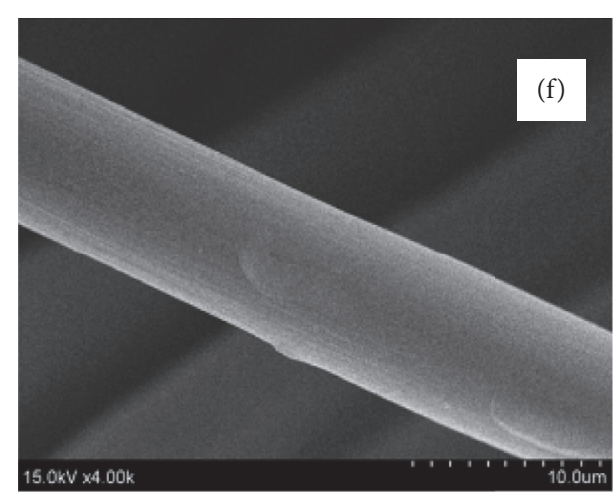

(f)

FIGURE 7: SEM micrographs of the electrode surface: (a) and (b) unmodified carbon cloth; (c) and (d) PEI modified carbon cloth; (e) and (f) GOx/PEI modified carbon cloth.

3.5. SEM Surface Observation. SEM observation was used to observe the enzyme immobilized on the electrode surface. Before the carbon cloth electrode modification, the electrode surface was clearly rough and had longitudinal fiber morphology, as shown in Figures 7(a) and 7(b). To further examine the enzyme GOx immobilized on the carbon cloth electrode, the PEI and GOx/PEI coated carbon cloth electrode surface was observed, Figures 7(c), 7(d), 7(e), and 7(f), respectively. The PEI modified carbon cloth electrode surface was slightly smoother than the unmodified carbon cloth because there was PEI covered on the fiber surface. However, the GOx/PEI catalyst-coated carbon cloth had a plain surface, as shown in Figures 7(e) and 7(f). This proves that the PEI carrier and the GOx loading successfully covered the carbon cloth fiber.

3.6. Self-Pumping EGBC Test Analysis. To realize the GOx/ PEI effect on self-pumping EGBC performance, polarization curves were measured with the results shown in Figure 8. Comparing the electrical performance of the modified chitosan (CS) GOx/CS self-pumping EGBC [17] with the GOx/PEI EGBC, the GOx/PEI modified anode electrode demonstrated better function than the GOx/CS electrode while the experimental conditions and parameters performed the same. The maximum power density was $0.609 \mathrm{~mW} / \mathrm{cm}^{2}$ and optimum volume power density was $126.9 \mathrm{~mW} / \mathrm{cm}^{3}$ 


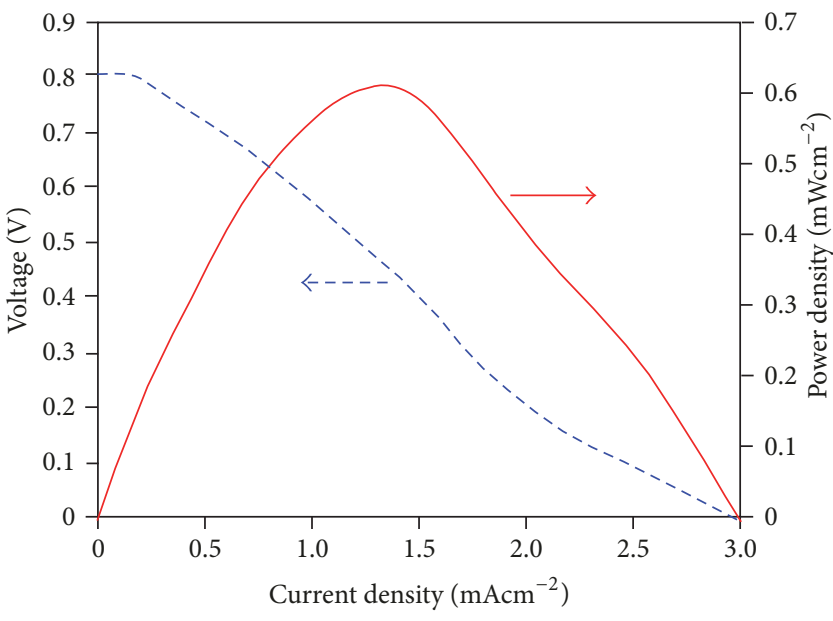

(a)

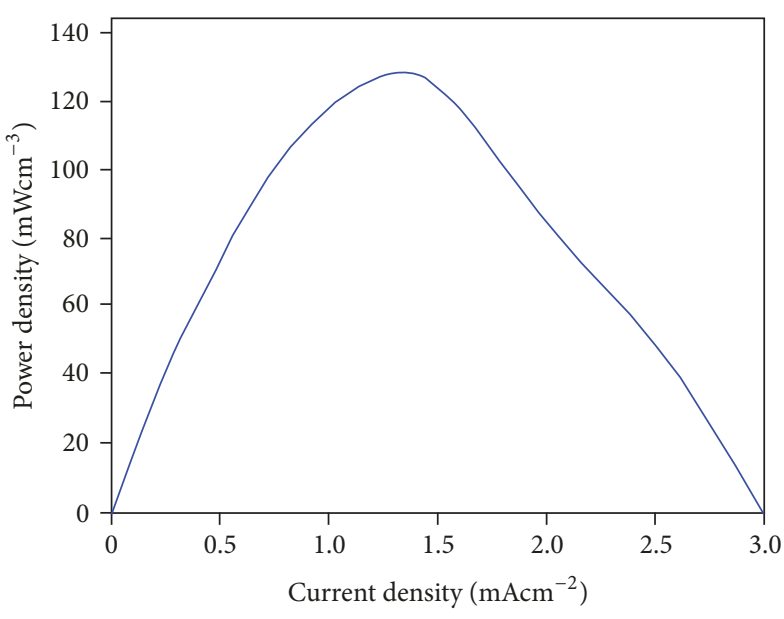

(b)

FIgURE 8: Polarization curves of self-pumping EGBC adopting the GOx/PEI as an enzymatic anodic catalyst and carbon paper-coated Pt catalyst as the cathode electrode. (a) Area power density. (b) Volume power density.

TABle 2: Comparison of system characteristics between GOx/PEI and GOx/CS self-pumping EGBC.

\begin{tabular}{lcc}
\hline & $\begin{array}{c}\text { This work } \\
(\mathrm{GOx} / \mathrm{PEI})\end{array}$ & $\begin{array}{c}\text { Previous work } \\
(\mathrm{GOx} / \mathrm{CS})[17]\end{array}$ \\
\hline $\begin{array}{l}\text { Area power density } \\
\left(\mathrm{mW} / \mathrm{cm}^{2}\right)\end{array}$ & $0.609 \pm 0.015$ & $0.534 \pm 0.016$ \\
$\begin{array}{l}\text { Volume power density } \\
\left(\mathrm{mW} / \mathrm{cm}^{3}\right)\end{array}$ & $126.9 \pm 3.2$ & $111.2 \pm 3.3$ \\
\hline
\end{tabular}

when the voltage was $0.48 \mathrm{~V}$, as shown in Figure 8 . System characteristics and performance comparison between the GOx/PEI and GOx/CS self-pumping EGBC is shown in Table 2.

\section{Conclusions}

The GOx/PEI carbon cloth electrode was used in selfpumping EGBC. Liquid fuel was driven into the fuel cell using capillary force without any extra pump. The results show that the GOx/PEI electrode has excellent hydrophilicity on the $\mathrm{GOx} / \mathrm{PEI}$ electrode surface by contact angle measurement. In the optical and electrochemical analysis results, GOx/PEI was successfully immobilized onto the carbon cloth electrode. According to the experimental analysis for self-pumping EGBC showing $0.609 \mathrm{~mW} / \mathrm{cm}^{2}\left(126.9 \mathrm{~mW} / \mathrm{cm}^{3}\right)$ maximum power output was achieved. The PEI contributes to the shortening of the process from a few hours to within 10 minutes, thereby enhancing self-pumping EGBC performance.

\section{Data Availability}

The data used to support the findings of this study are available from the corresponding author upon request.

\section{Disclosure}

An earlier version of this work was presented at "International Symposium on Green Manufacturing and Applications," 2017.

\section{Conflicts of Interest}

The authors declare that they have no conflicts of interest.

\section{Acknowledgments}

This work was supported by the Ministry of Science and Technology of Taiwan (Grant no. MOST105-2221-E-005064).

\section{References}

[1] H. Moon, I. S. Chang, and B. H. Kim, "Continuous electricity production from artificial wastewater using a mediator-less microbial fuel cell," Bioresource Technology, vol. 97, no. 4, pp. 621-627, 2006.

[2] B. H. Kim, I. S. Chang, G. C. Gil, H. S. Park, and H. J. Kim, "Novel BOD (biological oxygen demand) sensor using mediator-less microbial fuel cell," Biotechnology Letters, vol. 25, no. 7, pp. 541-545, 2003.

[3] S. C. Barton, J. Gallaway, and P. Atanassov, "Enzymatic biofuel cells for implantable and microscale devices," Chemical Reviews, vol. 104, no. 10, pp. 4867-4886, 2004.

[4] U. Bilitewski, "Protein-sensing assay formats and devices," Analytica Chimica Acta, vol. 568, no. 1-2, pp. 232-247, 2006.

[5] F. Rusmini, Z. Zhong, and J. Feijen, "Protein immobilization strategies for protein biochips," Biomacromolecules, vol. 8, no. 6, pp. 1775-1789, 2007.

[6] M. Cretich, F. Damin, G. Pirri, and M. Chiari, "Protein and peptide arrays: Recent trends and new directions," Biomolecular Engineering, vol. 23, no. 2-3, pp. 77-88, 2006. 
[7] M. M. Anderson and R. H. Kaul, "Protein stabilizing effect of polyethyleneimine," Journal of Biotechnology, vol. 72, pp. 21-31, 1999.

[8] Y. Chung, K. H. Hyun, and Y. Kwon, "Fabrication of a biofuel cell improved by the $\pi$-conjugated electron pathway effect induced from a new enzyme catalyst employing terephthalaldehyde," Nanoscale, vol. 8, no. 2, pp. 1161-1168, 2016.

[9] C. Xu, L. Zhang, L. Liu et al., "A novel enzyme-free hydrogen peroxide sensor based on polyethylenimine-grafted graphene oxide-Pd particles modified electrode," Journal of Electroanalytical Chemistry, vol. 731, pp. 67-71, 2014.

[10] C. Deng, J. Chen, Z. Nie, and S. Si, "A sensitive and stable biosensor based on the direct electrochemistry of glucose oxidase assembled layer-by-layer at the multiwall carbon nanotubemodified electrode," Biosensors and Bioelectronics, vol. 26, no. 1, pp. 213-219, 2010.

[11] S. Vogt, M. Schneider, H. Schäfer-Eberwein, and G. Nöll, "Determination of the $\mathrm{pH}$ dependent redox potential of glucose oxidase by spectroelectrochemistry," Analytical Chemistry, vol. 86, no. 15, pp. 7530-7535, 2014.

[12] X. Yang, W. Yuan, D. Li, and X. Zhang, "Study on an improved bio-electrode made with glucose oxidase immobilized mesoporous carbon in biofuel cells," RSC Advances, vol. 6, no. 29, pp. 24451-24457, 2016.

[13] H. Sakai, T. Nakagawa, Y. Tokita et al., "A high-power glucose/oxygen biofuel cell operating under quiescent conditions," Energy \& Environmental Science, vol. 2, no. 1, pp. 133-138, 2009.

[14] B. Mecheri, A. Geracitano, A. D’Epifanio, and S. Licoccia, "A glucose biofuel cell to generate electricity," in Proceedings of the Bioelectrocatalysis - 219th ECS Meeting, pp. 1-8, can, May 2011.

[15] R. E. Kim, S.-G. Hong, S. Ha, and J. Kim, "Enzyme adsorption, precipitation and crosslinking of glucose oxidase and laccase on polyaniline nanofibers for highly stable enzymatic biofuel cells," Enzyme and Microbial Technology, vol. 66, pp. 35-41, 2014.

[16] S. Şahin, T. Wongnate, L. Chuaboon, P. Chaiyen, and E. H. $\mathrm{Yu}$, "Enzymatic fuel cells with an oxygen resistant variant of pyranose-2-oxidase as anode biocatalyst," Biosensors and Bioelectronics, vol. 107, pp. 17-25, 2018.

[17] Y.-F. Tsai, H. Yang, and C.-J. Shieh, "Capillary force pumping fluid for glucose oxidase enzymatic fuel cells," in Proceedings of the 2015 Symposium on Design, Test, Integration and Packaging of MEMS/MOEMS (DTIP), pp. 1-6, Montpellier, France, April 2015.

[18] G. Zhang, S. Sun, D. Yang, J.-P. Dodelet, and E. Sacher, “The surface analytical characterization of carbon fibers functionalized by $\mathrm{H} 2 \mathrm{SO} 4 / \mathrm{HNO} 3$ treatment," Carbon, vol. 46, no. 2, pp. 196205, 2008. 

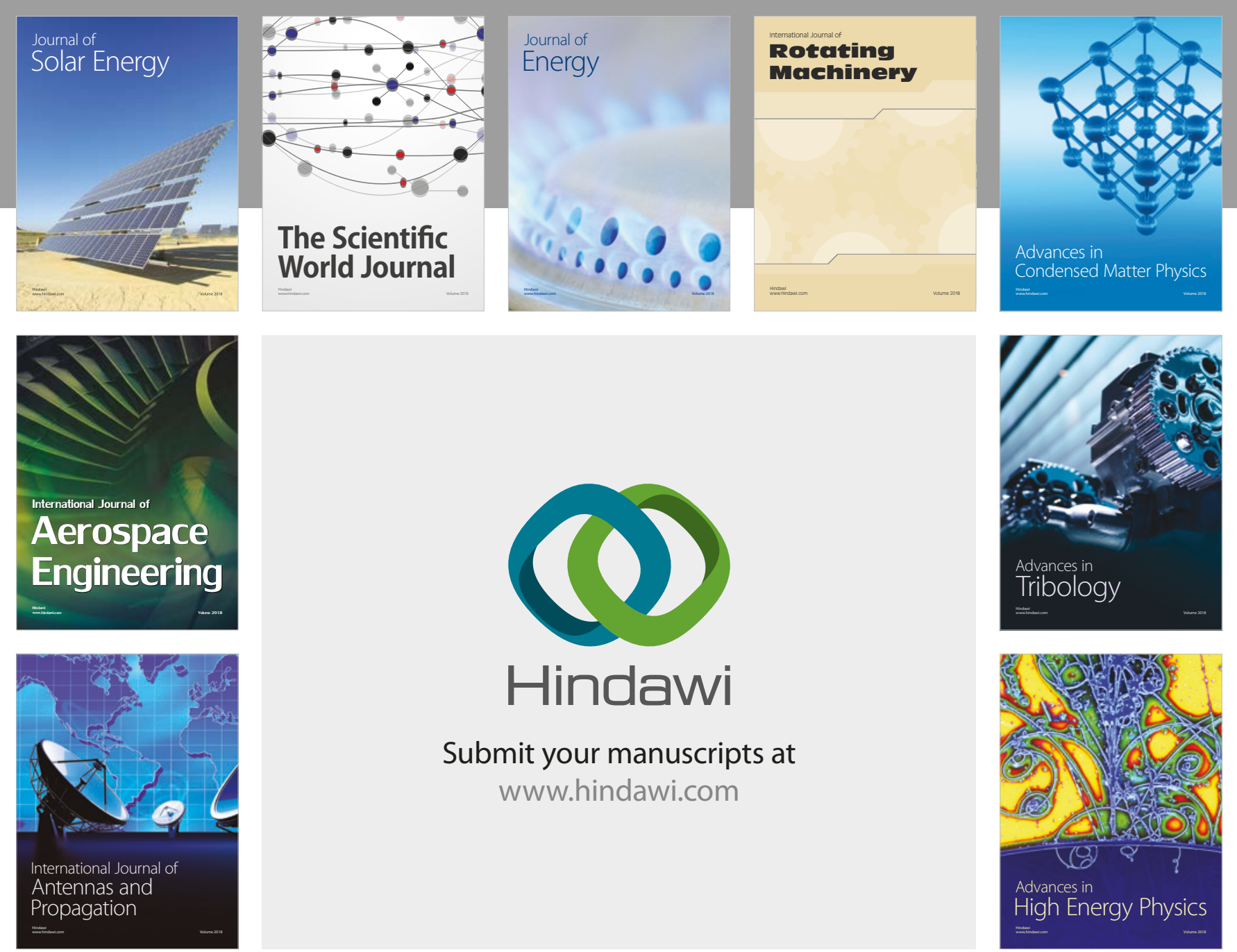

Submit your manuscripts at

www.hindawi.com
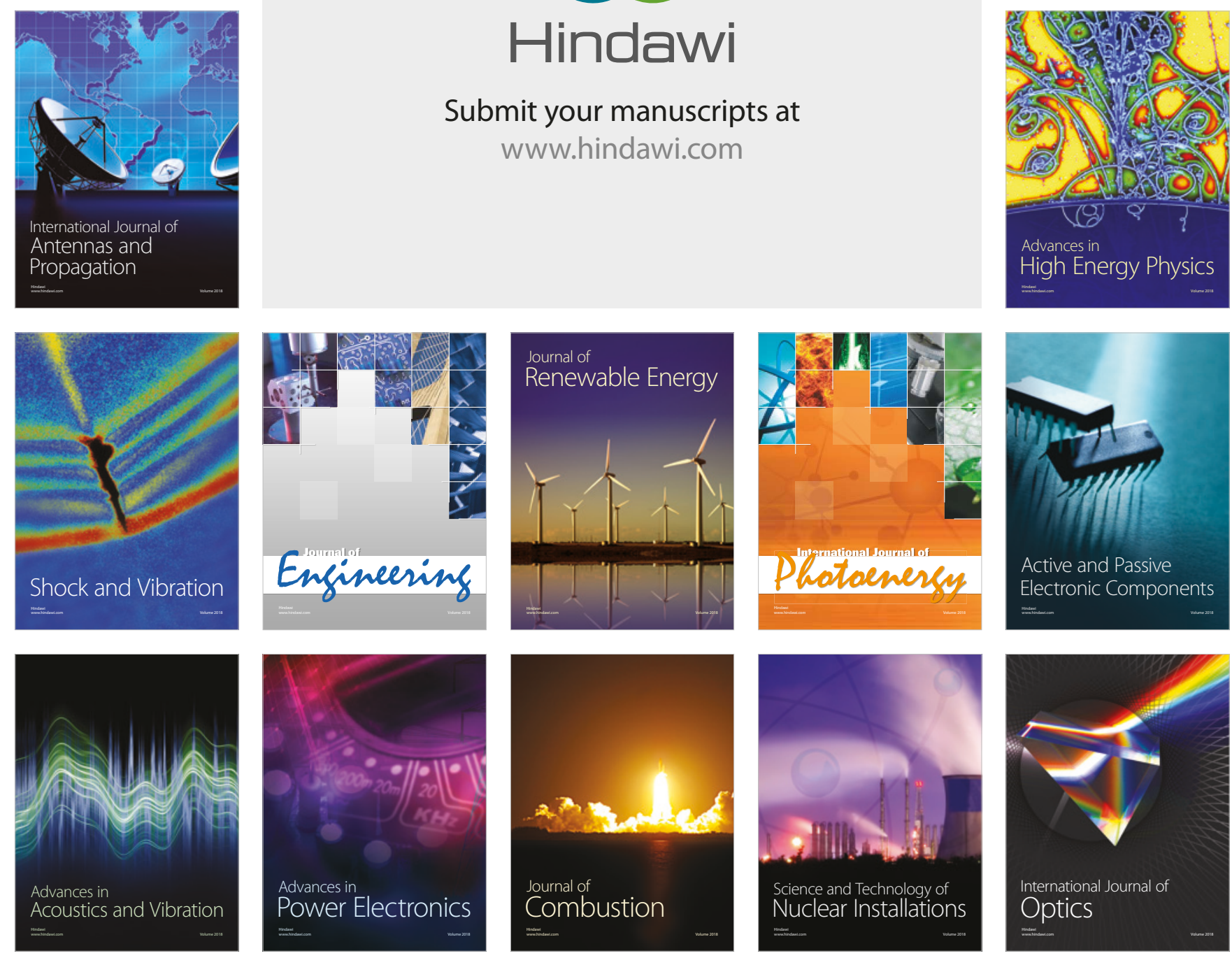